\title{
SOCIAL PROBLEMS IN POST-DIVORCED SINGLE-PARENT FAMILIES
}

\section{GALINA KANTEMIROVA}

The intensity and dynamics of modern social processes have resulted in a crisis of a family, including a decline in birth rate, growth in numbers of divorces, and illegitimate births. The subject of divorce is especially vital nowadays since it has a tendency to increase.

A history of divorces has started simultaneously with a history of marital relations and has been known since ancient times, though, in countries of Europe divorces related to breaches of marital agreement by one side or both sides were strictly regulated during the Modern Age ${ }^{1}$. No-fault divorce, without breach of marital agreement, in its present-day form, originated in the USA and quickly spread throughout the country with its maximum rate of 5,3 divorces per 1000 population in $1981^{2}$. Nowadays this amount is equal to 3,4 divorces per 1000 population per year or to $40 \%$ of all first marriages ${ }^{3}$.

According to the statistics, cases of the reunion of marriage partners are exposed to a higher risk of divorce in comparison with the first marriage ${ }^{4}$. In countries with more liberal regulations, for example, in the Netherlands, the divorce rate is even higher. In general, the total divorce rate in this country increased from 3,0/1000 in 1950 up to 9,8/1000 in 2000, with a slight decrease to 8,9 in $2009^{5}$. Among other things, divorce has a negative impact on a lifetime: the average life span of divorced women decreased by $27 \%$ and of men by $10 \%{ }^{6}$.

Divorce experience propagation mechanism in micro-social networks may be connected, firstly, with "transmissibility", when a divorce of one member of the micro-social network can accelerate or decelerate a divorce of others, secondly, with the occurrence of "humanistic binding", when individuals with

${ }^{1}$ Phillips R., Putting asunder: A history of divorce in Western society. Cambridge: Cambridge University Press, 1988.

${ }^{2}$ Amato P. R., Irving S., Historical trends in divorce in the United States (M. A. Fine, J. H. Harvey (Eds.), Handbook of divorce and relationship dissolution. Mahwah, NJ: Erlbaum, 2006, p. 41-57.

3 Bramlett M. D., Mosher W. D., Cohabitation, marriage, divorce, and remarriage in the United States. Hvattsville. MD: National Center for Health Statistics. 2002.

${ }_{4}$ Kreider R. M. et al., Number, Timing, and Duration of Marriages and Divorces. US. Census Bureau, 2002. 2010 .

${ }^{5}$ Central Bureau voor de Statistiek. Huwelijksontbindingen door echtscheiding, October,

${ }^{6}$ Peterson R.A., Re-evaluation of the economic consequences of divorce. American Sociological Review, 1996, N.61, p. 528-536. 
similar social and family status are inclined to initiation of more friendly ties with one another and, thirdly, exposure to similar external factors, e.g. economic, can also modulate the possibility of divorce within one micro-social group $^{7}$.

An issue of social "transmissibility" of divorce has been discussed in the literature many times. In the middle of XX century, it was illustrated that those marriage partners having common friends, i.e. included in the common microsocial network, are less inclined to divorce ${ }^{8}$. Other researchers, using nationalrepresentative samples, have demonstrated that weaker micro-social ties of one of the partners create a higher risk of marital unfaithfulness and, therefore, higher risk of divorce ${ }^{9}$. Some researchers emphasize the ambiguousness of social influence on family stability: "a mere fact of involvement into a microsocial network may not be enough to explain why some marriages are broken while other marriages are not" ${ }^{\prime 10}$.

Although much attention has been given to the influence of divorce on children, publications describing the influence of children on divorce are relatively few. It was shown that existence of first-borns in the family until arriving at their school-age usually support family stability and minimize divorce risks. Subsequent children have a similar effect on the risk of divorce but only during their infancy. The existence of children born outside the marriage or children of higher age has a negative effect on the stability of a family. Researchers assume that this effect on marriage caused by existing children is due to the fact that the inevitable increase of costs, in this case, is neutralized by multiple immediate tasks of married partners related to little baby childcare. When a child grows up and becomes more self-dependent, the necessity to keep a marriage "for the sake of the children" becomes less important. Besides, during this period, the "postponed" arguments like attempts to avoid a child's stress connected with possible divorce, also have less importance to keep the marriage $^{11}$.

Another research study based on regressive analysis shows that a stabilizing effect on marriage is registered only when there are no more than 3 children in the family. If the number is higher, the possibility of divorce increases ${ }^{12}$.

One of the possible ways of transmissibility of divorce through the micro-

${ }^{7}$ Christakis N.A., Fowler J.H., Social Contagion Theory: Examining Dynamic Social Networks and Human Behavior // Stat. Med, 2013, N. 32(4), p. 556-577.

8 Ackerman C., Affiliations: Structural Determinants of Differential Divorce Rates, American Journal of Sociology, 1963, N. 69, p. 13-20.

9 Treas J., Giesen D., Sexual Infidelity among Married and Cohabiting Americans, Journal of Marriage and the Family, 2000, N.62, p. 48-60.

${ }^{10}$ Booth A, Edwards J, Johnson D., Social Integration and Divorce, Social Forces, 1991, N. 70, p. 207-224.

${ }_{11}$ Waite L., Lillard L., Children and Marital Disruption, American Journal of Sociology, 1991, N.96 (4), p. 930-953. N.27, p. 55.

${ }_{12}$ Heaton T., Marital stability throughout the child rearing years, Demography, 1990, 
level social network is a vertical transgenerational transmission. It is about the children of those parents who got divorced and who are more inclined to get divorced in their own marriage compared to their same-age peers who grew up in two-parent stable families ${ }^{13}$. Another research shows that the risk of divorce for those girls who grew up in a splat family was higher by $70 \%$ of the average number of divorces ${ }^{14}$. The researchers also point out an indirect influence of parental separation on their children: for example, girls grown up in singleparent families are more focused on building their career, planned fewer children, aimed at the economic independence from men. Besides, a phenomenon of lasting extramarital relationship is typical for children from single-parent families ${ }^{15}$.

The age of married partners influences family stability too: early marriages not only have a higher risk to end up in divorce but also children born in such marriages are more inclined to enter into early marriages. This can be treated as another way of vertical transgenerational transmission (transmissibility) of divorce $^{16}$.

Another mechanism of transmissibility of divorce of such type is the replication of parental behavioral patterns by their children. For example, children from single-parent families are more likely to copy their parents' distrust of each other, jealousy, offensive behavior patterns, but not to adopt interpersonal communication comprising trust and ability to compromise ${ }^{17}$.

The cultural-religious aspect is also important while evaluating the divorce risks; according to available research data, marriage partners following the same religion have more chances for a stable marriage compared to the partners representing different religious beliefs ${ }^{18}$.

Based on data of polls held between 1971 and 2001 with 4,5 thousand respondents, Dermott et al showed that within micro-social networks divorces had a tendency to cluster formation, i.e. divorce of one couple frequently provoked divorces of other couples having social ties with each other. The authors found out that this social clusterization effect of divorces is weakly dependent on the geographical location of micro-social network elements but highly dependent

${ }^{13}$ Feng D. et al, Intergenerational Transmission of Marital Quality and Marital Instability, Journal of Marriage and the Family, 1999, N.61, p. 451-463.

${ }^{14}$ Bumpass L., Martin R., Sweet J., The impact of family background and early marital factors on marital disruption, Journal of Family Issues, 1991, N.12, p. 22-42.

${ }^{15}$ Thornton A., Influence of the marital history of parents on the marital and cohabitation experiences of children, American Journal of Sociology, 1991, N. 96, p. 868 - 894; Goldscheider E., Waite L., New families, no families: the transformation of the American home, 1991, Berkeley, University of California Press.

${ }^{16}$ Keith V., Finlay B., The impact of parental divorce on children's educational attainment, marital timing, and likelihood of divorce, Journal of Marriage and the Family, 1988, N.50, p. 707-809.

${ }^{17}$ Teachman J., Stability Across Cohorts in Divorce Risk Factors, Demography, 2002, N.39, p. 331-351.

${ }^{18}$ Lehrer E., Chiswick C., Religion as a Determinant of Marital Stability, Demography, 1993, N.30, p. 385-404. 
on social distance between different members of such networks. Edges of such divorce clusters were determined by the authors as 1-2 levels of social ties ${ }^{19}$.

As for the influence of micro-social networks on divorce, the authors came to conclusion that this influence only strengthened partners' wish to protect their marriage: in the case of a stable marriage, the social environment common for both partners is stimulating the marriage, but in case of poor family relations, this environment might accelerate further disruption of the family.

Divorce, in the opinion of the authors, negatively impacts the social environment around a divorced individual since such individuals become less popular within their social network. This may ensue from the loss of a part of the social environment belonging to another partner and also due to the fact that divorced individuals are perceived by other married couples in their network as a threat to their own marriage. The authors do not see any gender specifics in horizontal social network transmissibility of divorce: social effects of divorces observed had the same effect both on men and women ${ }^{20}$.

The vertical (intergenerational) transmissibility of higher risk of divorce was attested more than 10 years ago. Other research studies, done at the same time, showed that the divorce of parents was one of the most important factors which determined the possibility of divorce of their children. Numerous investigators searched for possible mechanisms of transference of this risk. In different research works the analysis has been done of such aspects as the length of marriage, the balance of family prospects in this social-economic environment; unhappy marriages were simulated with respect to the developmental level of interpersonal communication technique and specifics of selection of a preferred partner $^{21}$. All these studies were carried out on the assumption of the existence of a causal relationship between the levels of risk of divorce in different generations, i.e. the causal nature of the relationship between these indicators was recognized.

However, it can be assumed that the statistical relationship between the levels of risk of divorce in subsequent generations is non-causal; more precisely, the relationship of these indicators contains hidden mediating factors (distorting factors, see pic. 1).

${ }^{19}$ McDermott R. et al, Breaking Up is Hard to Do Unless Everyone Else is Doing It Too: Social Network Effects on Divorce in a Longitudinal Sample, Soc. Forces, 2013, N. 92(2), p. 491519; Pryor J, Rogers B., Children in changing families: Life after parental separation, Boston: Blackwell, 2001.

${ }^{20}$ Ibid.

${ }^{21}$ Amato P.R., Children of divorced parents as young adults. (Hetherington E.M., ed.), Coping with divorce single parenting and remarriage: A risk and resiliency perspective. Mahwah, NJ: Erlbaum, 1999, p. 147-163; Fine M.A., Harvey J.H., eds., Handbook of divorce and relationship dissolution, Mahwah, NJ: Erlbaum, 2006. 
The indirect nature of the relationship between the risk of divorce of parents and descendants

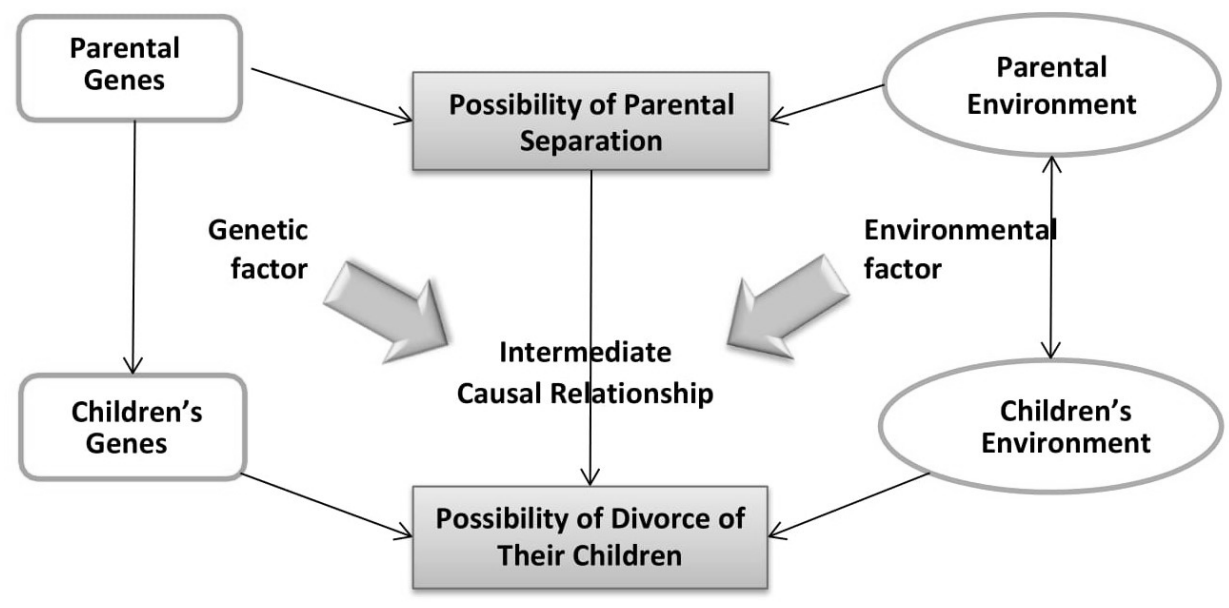

The picture 1 illustrates the indirect nature of the relationship between the risk of divorce of parents and children as the interaction of two mediating factors: genetic and environmental. The most obvious is the environmental factor. An example of this is socioeconomic status: families living in poverty are characterized by shorter marriage times and higher divorce rates. Thus, socioeconomic status becomes a mediating variable, influencing both the likelihood of parental divorce and the likelihood of divorce of their children.

The severity of psychopathological representation in parents, which obviously affects the likelihood of divorce, can serve as a kind of transitional step from environmental to genetic factors. This characteristic is determined by both the influence of the external environment and the genetic characteristics of individuals ${ }^{22}$.

Genetic factors also largely determine the stability of marriage relations created by individuals, which was shown back in the 80 s of the twentieth century. Twin studies have shown that a direct influence of genetic factors on the likelihood of divorce is possible. Although genetic factors directly, most likely, have a small effect on the likelihood of divorce, to a much greater extent they control the features of the endophenotype, which strongly affect the likelihood of divorce. As examples of such influence, one can name such personality traits as a tendency to neurotization or to antisocial behavior, which cannot but influence the likelihood of divorce. Behavioral genetics studies confirm that genetic factors determine the severity of such negative psychopathological manifesta-

${ }^{22}$ Schleider J.L., Weisz J.R., Relation Between Parent Psychiatric Symptoms and Youth Problems: Moderation through Family Structure and Youth Gender, Child. Psychol, 2013, N. 42, p. 195-204. 
tions. Twin studies also show that such personality traits partially determine genetic influences on the likelihood of divorce ${ }^{23}$.

One should also separate the risk factors itself and the mechanisms of their influence on the expected consequences. A risk factor such as parental divorce will inevitably have environmental consequences for the children of a divorced couple (mechanism of action of the risk factor), regardless of whether environmental or genetic factors (source of risk) were predominant in this case of divorce. Since experimental research in this area is difficult, researchers are usually forced to use research designs that would separate the influence of various, for example, genetic and environmental factors on the likelihood of divorce and make it possible to study them separately. The need to include studies of the genetics of behavior in the study of intergenerational transmission of the degree of risk of divorce is confirmed by both the opinion of researchers of family psychology and child psychologists ${ }^{24}$.

Currently, most researchers in this area assess the differences between children from complete and single-parent families. Such research designs allow to take into account many environmental factors influencing the likelihood of divorce, but cannot exclude the influence of the genetic heterogeneity of the research objects. The situation can be somewhat improved by using the method of twin studies, when the effects of divorce on the children of divorced twins are investigated in comparison with the children of undivided ones ${ }^{25}$. The descendants of genetically identical twins represent a unique object of research in this respect. Since they are $50 \%$ genetically identical, it becomes possible to observe genetic risk factors for divorce. In addition, in such cases, the influence of observed and unobservable environmental factors is leveled, since the twins share not only genes, but also the environmental conditions in which they grew up. In this regard, it is interesting to compare the effect of parental divorce on children from mono - and dizygotic twins due to the differences in their ge-

${ }^{23}$ See, for example: Scarr S., McCartney K., How people make their own environments: A theory of genotype environment effects, Child Development, 1983, N.54, p. 424-435; D'Onofrio B.M. et al., A genetically informed study of marital instability and its association with offspring psychopathology, Journal of Abnormal Psychology, 2005, N.114, p. 570-586; Gottesman I.I., Gould T.D., The endo phenotype concept in psychiatry: Etymology and strategic intentions, American Journal of Psychiatry, 2003, N.160, p. 636-645; Karney B.R., Bradbury T.N., The longitudinal course of marital quality and stability: A review of theory, method, and research, Psychological Bulletin, 1995, N.118, p. 3-34; Emery R.E. Marriage, Divorce, and children's adjustment. Thousand Oaks, CA: Sage, 1999; Rhee S.H., Waldman I.D., Genetic and environmental influences on antisocial behavior: A meta-analysis of twin and adoption studies. // Psychological Bulletin, 2002, N.128, p. 490-529; Jockin V., McGue M., Lykken D.T., Personality and divorce: A genetic analysis, Journal of Personality and Social Psychology, 1996, N. 71, p. 288299.

${ }^{24}$ See: Rutter M., et al., Testing hypotheses on specific environmental causal effects on behavior, Psychological Bulletin, 2001, N 127, p. 291-324; Booth A., Carver K., Granger D.A., Biosocial perspectives on the family, Journal of Marriage and the Family, 2000, N 62, p. 10181034; Collins W.A. et al., Contemporary research on parenting: The case for nature and nurture, American Psychologist, 2000, N.55, p. 218-232.

${ }^{25}$ Rodgers J., Cleveland H., van den Oord E., Rowe D., Resolving the debate over birth order, family size, and intelligence, American Psychologist, 2000, N.55, p. 599-612. 
nomes. The difference in the effect of divorce when comparing these children will indicate the genetic factors that determine this difference.

This method also has its disadvantages; it cannot take into account those environmental factors that affect only one of the twins. Thus, the following circumstances are currently recognized as risk factors for divorce:

- early marriage,

- poverty at marriage,

- unemployment upon marriage,

- low level of education upon marriage,

- having children before marriage (especially for women),

- interracial and interethnic marriages,

- second or subsequent marriage,

- origin from a divorced family ${ }^{26}$.

It should be noted that although these factors are, according to the literature, risk factors for divorce, they may not be the cause. Thus, the literature continues to debate the role of premarital cohabitation as a factor influencing the stability of marriage. Despite the seemingly usefulness of premarital cohabitation in allowing future spouses to get to know each other better, research shows that cohabitation is one of the risk factors for divorce, especially if you have a child born during such cohabitation. It was also shown that couples living together outside of wedlock, even if such cohabitation is associated with conflicts and tension, and partners do not suit each other in everything, nevertheless, are inclined to marry due to some "inertia" of cohabitation ${ }^{27}$.

For a long time, it was believed that a wife's own economic resource base reduces the stability of a marriage. According to the researchers, such wives have a heightened perception of household problems and the unfair distribution of domestic work. However, studies of recent decades have questioned this position. Thus, researchers believe that the wife's employment and her own income can increase the stability of the marriage by improving the resource security of the family. Longitudinal studies in this area show that having an

${ }^{26}$ Teachman J., Premarital sex, premarital cohabitation, and the risk of subsequent marital dissolution among women, Journal of Marriage and Family, 2003, V. 65, p. 444-455; Sweeney M. M., Phillips J. A., Understanding racial differences in marital disruption: Recent trends and explanations, Journal of Marriage and Family, 2004, V. 66, p. 639-650; Bramlett M. D., Mosher W. D., Cohabitation, marriage, divorce, and remarriage in the United States. Vital and Health Statistics, Series 23. Washington, DC: U.S. Government Printing Office, 2002; Bratter J., King R. B., But will it last. Marital instability among interracial and same race couples, Family Relations, 2008, V. 57, p. 160-171; Amato P. R., DeBoer D., The intergenerational transmission of marital instability across generations: Relationship skills of commitment to marriage? Journal of Marriage and Family, 2001, V. 63, p. 1038-1051.

${ }^{27}$ Brown S. L., Moving from cohabitation to marriage: Effects on relationship quality, Social Science Research, 2004, V. 33, p. 1-19; Tach L., Halpern Meekin S., How does premarital cohabitation affect trajectories of marital quality? Journal of Marriage and Family, 2009, V. 71, p. 298317; Stanley S. M., Rhoades G. K., Markman H. J., Sliding versus deciding: Inertia and the premarital cohabitation effect, Family Relations, 2006, V. 55, p. 499-510. 
independent income for wives has a "catalytic effect" on marriage: it strengthens harmonious marriages and contributes to the destruction of inharmonious, stressful marriages ${ }^{28}$.

Psychological factors that determine the characteristics of interpersonal communication between spouses play an important role in ensuring the stability of marriage. According to experts who have conducted longitudinal studies, the following factors in this group are associated with the risk of divorce:

- domestic violence,

- frequent conflicts,

- infidelity,

- low involvement in marriage,

- low level of trust of spouses to each other ${ }^{29}$.

Experts in this field note that research in the past has not paid sufficient attention to the role of positive psychological manifestations in the stabilization of marital relations. According to them, such negative features of the psyche as insufficient development of communication skills have a negative impact on the stability of marriage only in cases where there are no positive psychological manifestations between the spouses, such as humor, displays of affection, interest, etc. Another group of researchers also believes that modern literature on this issue pays too much attention to such manifestations as family aggression and conflict, ignoring such phenomena as self-sacrifice and tolerance in the family ${ }^{30}$.

Despite the fact that these psychological factors are associated with an increased likelihood of family breakdown, not all married couples had such psychological phenomena before divorce. Thus, when performing a longitude study, the presence of two groups of broken families was found. In families

${ }^{28}$ Frisco M. L., Williams K., Perceived housework equity, marital happiness, and divorce in dual earner households, Journal of Family Issues, 2003, V. 24, p. 51-73; Amato P. R., Booth A., Johnson D. R., Rogers S. J., Alone together: How marriage in America is changing, Cambridge, MA: Harvard University Press, 2007; Schoen R., Astone N. M., Rothert K., Standish N. J., Kim Y. J., Women's employment, marital happiness, and divorce, Social Forces, 2002, 81, p. 643-662.

${ }^{29}$ Lawrence E., Bradbury T. N., Physical aggression and marital dysfunction: A longitudinal analysis, Journal of Family Psychology, 2001, V. 15, p. 135-154; DeMaris A., Till discord do us part: The role of physical and verbal conflict in union disruption, Journal of Marriage and the Family, 2000, V. 62, p. 683-692; Previti D., Amato P. R., Is infidelity a cause or a consequence of poor marital quality? Journal of Social and Personal Relationships, 2004, V. 21, p. 217-230; Hall J. H., Fincham F.D., Relationship dissolution after infidelity, M. Fine, J. Harvey (Eds.), Handbook of divorce and relationship dissolution, Hillsdale, NJ: Erlbaum, 2006, p. 153-168; Clements M. L., Stanley S. M., Markman H. J., Before they said, "I do": Discriminating among marital outcomes over 13 years, Journal of Marriage and Family, 2004, V. 66, p. 613-626; Gottman J. M., Levenson R. W., The timing of divorce: Predicting when a couple will divorce over a 14 year period, Journal of Marriage and the Family, 2000, V. 62, p. 737-745.

${ }^{30}$ Bradbury, T.N., Karney, B. R., Understanding and altering the longitudinal course of the marriage, Journal of Marriage and Family, 2004, 66, p. 862-879; Fincham, F. D., Stanley, S. M., Beach, S. R., Transformative processes in marriage: An analysis of emerging trends. Journal of Marriage and Family, 2007, 69, p. 275-293. 
from the same group, before the divorce, pronounced representation of aggression, conflicts and even physical violence were revealed, as well as frequent thoughts of spouses about divorce. In another group of broken families, these manifestations were absent or were much less pronounced. For both groups of families, it was characteristic that the spouses grew up in divorced families, they were weakly religious, or were in a second or subsequent marriage. The authors come to the conclusion that the common reasons for divorce can be the incompatibility of the spouses, which causes a high level of conflict, or the weak involvement of the spouses in the marriage ${ }^{31}$.

From the presented material, we can make a general conclusion that the social dynamics of types of family structure obeys some objective laws and depends on the balance of provoking and inhibiting social factors specific to each specific type of family structure.

\section{Conclusions}

It is possible to distinguish the vertical (intergenerational) and horizontal (intragenerational) types of transmission of the family structure. Vertical transmission determines the increased likelihood of reproduction of the parental type of family structure by children. The horizontal transmission path is the possibility of a certain type of family structure to spread through microsocial networks within a certain age and social stratum. The mediated nature of the relationship between the family structure of parents and children is the mutual influence of two mediating factors - genetic and environmental ones. In the structure of these factors, provoking and inhibiting elements can be distinguished in relation to one or another type of family structure. Currently, the following circumstances are most often recognized as provoking socio-economic characteristics toward an incomplete family: early marriage, poverty of the couples, unemployment of a partner (partners) while marrying, low level of education of the partners, children of a partner/s prior to the marriage (especially of a woman), interracial and interethnic marriages, second or subsequent marriage, partners originated from divorced families.

Key words: divorce, transmissibility of divorce, post-divorced situation, single-parent family

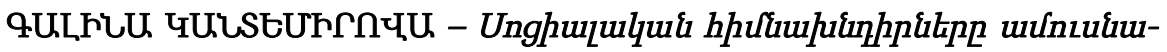

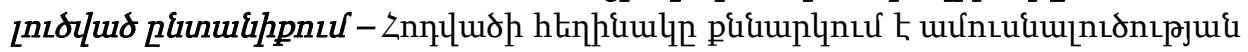

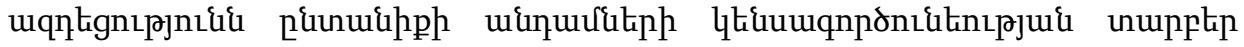

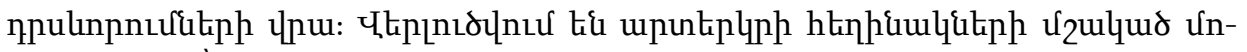

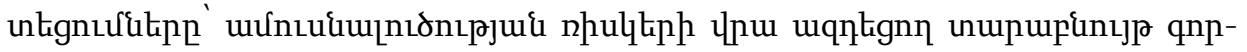

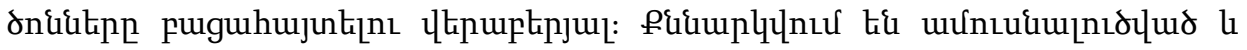

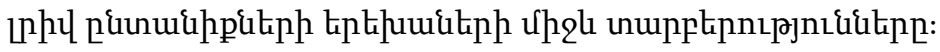

${ }^{31}$ Amato P. R., Hohmann Marriott B., A comparison of high and low distress marriages that end in divorce, Journal of Marriage and Family, 2007, V. 69, p. 621-638. 


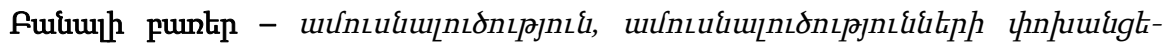

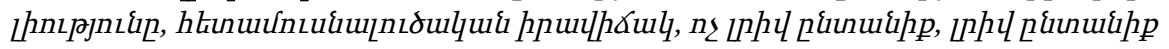

ГАЛИНА КАНТЕМИРОВА - Социальные проблемы в постразводной неполной семье. - В статье рассматривается влияние разводов на различные факторы жизни членов семьи. Проанализированы работы зарубежных исследователей, посвящённые средовым факторам, которые влияют на вероятность развода. Дана оценка различий между детьми из полных и неполных семей.

Ключевые слова: развод, контагиозность разводов, постразводная ситуачия, неполная семья

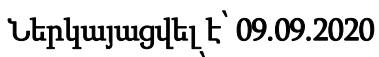

9pupunultil to 01.10.2020

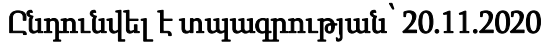




\begin{abstract}
The article examines the influence of divorce on various factors in the life of family members. The works of foreign researchers devoted to environmental factors that affect the likelihood of divorce are analyzed. An assessment of the differences between children from complete and incomplete families is given.
\end{abstract}

Keywords: Selected:divorce, transmissibility of divorce, post-divorced situation, single-parent family

\title{
About Authors
}

Galina Kantemirova - PhD, Associate Professor of the Chair of Social Work, North Ossetia State University after Kosta Khetagurov, Vladikavkaz, RF.

E mail: cantem.galina@yandex.ru

\section{REFERENCES}

Ackerman, C. (1963). Affiliations: Structural Determinants of Differential Divorce Rates, American Journal of Sociology, N. 69, 13-20. Doi: https://doi.org/10.1086/223506

Amato, P. R. \& DeBoer, D. (2001). The intergenerational transmission of marital instability across generations: Relationship skills of commitment to marriage? Journal of Marriage and Family, V. 63, 1038-1051. Doi: https://doi.org/10.1111/j.1741-3737.2001.01038.x

Amato, P. R. \& Hohmann Marriott, B. (2007). A comparison of high and low distress marriages that end in divorce, Journal of Marriage and Family, V. 69, 621-638. Doi:

https://doi.org/10.1111/j.1741-3737.2007.00396.x

Amato, P. R. \& Irving S. (2006). Historical trends in divorce in the United States (M. A. Fine, J. H. Harvey (Eds.), Handbook of divorce and relationship dissolution. Mahwah, NJ: Erlbaum, 4157.

Amato, P. R., Booth, A., Johnson, D. R. \& Rogers, S. J. (2007). Alone together: How marriage in America is changing, Cambridge, MA: Harvard University Press. Doi:

https://doi.org/10.4159/9780674020184

Amato, P.R. (1999). Children of divorced parents as young adults. (Hetherington E.M., ed.),

Coping with divorce single parenting and remarriage: A risk and resiliency perspective, Mahwah, NJ: Erlbaum, 1999, 147-163

Booth, A \& Edwards, J (1991). Johnson D., Social Integration and Divorce, Social Forces, N. 70, 207-224. Doi: https://doi.org/10.2307/2580069

Booth, A., Carver, K. (2000). Granger, D.A., Biosocial perspectives on the family, Journal of Marriage and the Family, N 62, 1018-1034. Doi: https://doi.org/10.1111/j.1741-

3737.2000.01018.x

Bradbury, T.N., Karney, B. R. (2004). Understanding and altering the longitudinal course of the marriage, Journal of Marriage and Family, 66, 862-879. Doi: https://doi.org/10.1111/j.00222445.2004.00059.x 
Bramlett, M. D. \& Mosher, W. D. (2002). Cohabitation, marriage, divorce, and remarriage in the United States. Vital and Health Statistics, Series 23. Washington, DC: U.S. Government Printing Office. Doi: https://doi.org/10.1037/e305022003-001

Bramlett, M. D. (2002). Mosher, W. D., Cohabitation, marriage, divorce, and remarriage in the United States. Hyattsville, MD: National Center for Health Statistics. Doi:

https://doi.org/10.1037/e305022003-001

Bratter, J. \& King, R. B. (2008). But will it last. Marital instability among interracial and same race couples, Family Relations, V. 57, 160-171. Doi: https://doi.org/10.1111/j.17413729.2008.00491.x

Brown, S. L. (2004). Moving from cohabitation to marriage: Effects on relationship quality, Social Science Research, V. 33, 1-19. Doi: https://doi.org/10.1016/S0049-089X(03)00036-X Bumpass, L., Martin R. \& Sweet J. (1991). The impact of family background and early marital factors on marital disruption, Journal of Family Issues, N.12, 22-42. Doi:

https://doi.org/10.1177/019251391012001003

Christakis, N.A. \& Fowler, J.H. (2013). Social Contagion Theory: Examining Dynamic Social Networks and Human Behavior. Stat. Med, N. 32(4), 556-577. Doi:

https://doi.org/10.1002/sim.5408

Clements, M. L., Stanley, S. M. \& Markman, H. J. (2004). Before they said, "I do":

Discriminating among marital outcomes over 13 years, Journal of Marriage and Family, V. 66, 613-626. Doi: https://doi.org/10.1111/j.0022-2445.2004.00041.x

Collins, W.A. et al. (2000). Contemporary research on parenting: The case for nature and nurture, American Psychologist, N.55, 218-232. Doi: https://doi.org/10.1037/0003-066X.55.2.218 D’Onofrio, B.M. et al. (2005). A genetically informed study of marital instability and its association with offspring psychopathology, Journal of Abnormal Psychology, N.114, 570-586. Doi: https://doi.org/10.1037/0021-843X.114.4.570

DeMaris, A. (2000). Till discord do us part: The role of physical and verbal conflict in union disruption, Journal of Marriage and the Family, V. 62, 683-692. Doi:

https://doi.org/10.1111/j.1741-3737.2000.00683.x

Emery, R.E. (1999). Marriage, Divorce, and children's adjustment. Thousand Oaks, CA: Sage Feng, D. et al (1999). Intergenerational Transmission of Marital Quality and Marital Instability, Journal of Marriage and the Family, N.61, 451-463. Doi: https://doi.org/10.2307/353761 Fincham, F. D., Stanley, S. M. \& Beach, S. R. (2007). Transformative processes in marriage: An analysis of emerging trends. Journal of Marriage and Family, 69, 275-293. Doi:

https://doi.org/10.1111/j.1741-3737.2007.00362.x

Fine, M.A. \& Harvey, J.H., (Eds.). (2006). Handbook of divorce and relationship dissolution,

Mahwah, NJ: Erlbaum

Frisco, M. L. \& Williams, K. (2003). Perceived housework equity, marital happiness, and divorce in dual earner households, Journal of Family Issues, V. 24, 51-73. Doi:

https://doi.org/10.1177/0192513X02238520

Goldscheider, E. \& Waite, L. (1991). New families, no families: the transformation of the American home, Berkeley, University of California Press 
Gottesman, I.I. \& Gould, T.D. (2003). The endo phenotype concept in psychiatry: Etymology and strategic intentions, American Journal of Psychiatry, N.160, 636-645. Doi:

https://doi.org/10.1176/appi.ajp.160.4.636

Gottman, J. M. \& Levenson, R. W. (2000). The timing of divorce: Predicting when a couple will divorce over a 14-year period, Journal of Marriage and the Family, V. 62, 737-745. Doi: https://doi.org/10.1111/j.1741-3737.2000.00737.x

Hall, J. H. \& Fincham, F.D. (2006). Relationship dissolution after infidelity, M. Fine, J. Harvey (Eds.), Handbook of divorce and relationship dissolution, Hillsdale, NJ: Erlbaum, 153-168 Heaton, T. (1990). Marital stability throughout the child rearing years, Demography, N.27, 55. Doi: https://doi.org/10.2307/2061552

Jockin, V., McGue, M. \& Lykken, D.T. (1996). Personality and divorce: A genetic analysis, Journal of Personality and Social Psychology, N. 71, 288-299. Doi: https://doi.org/10.1037/00223514.71.2.288

Karney, B.R. \& Bradbury, T.N. (1995). The longitudinal course of marital quality and stability: A review of theory, method, and research, Psychological Bulletin, N.118, 3-34. Doi:

https://doi.org/10.1037/0033-2909.118.1.3

Keith, V. \& Finlay, B. (1988). The impact of parental divorce on children's educational attainment, marital timing, and likelihood of divorce, Journal of Marriage and the Family, N.50, 707-809. Doi: https://doi.org/10.2307/352648

Kreider, R. M. et al. (2002). Number, Timing, and Duration of Marriages and Divorces. US. Census Bureau

Lawrence, E. \& Bradbury, T. N. (2001). Physical aggression and marital dysfunction: A longitudinal analysis, Journal of Family Psychology, V. 15, 135-154. Doi:

https://doi.org/10.1037/0893-3200.15.1.135

Lehrer, E. (1993). Chiswick, C., Religion as a Determinant of Marital Stability, Demography, N.30, 385-404. Doi: https://doi.org/10.2307/2061647

McDermott, R. et al (2013). Breaking Up is Hard to Do Unless Everyone Else is Doing It Too: Social Network Effects on Divorce in a Longitudinal Sample, Soc. Forces, N. 92(2), 491-519. Doi: https://doi.org/10.1093/sf/sot096

Peterson, R.A. (1996). Re-evaluation of the economic consequences of divorce. American Sociological Review, N.61, 528-536. Doi: https://doi.org/10.2307/2096363

Phillips, R. (1988). Putting asunder: A history of divorce in Western society. Cambridge: Cambridge University Press

Previti, D. \& Amato, P. R. (2004). Is infidelity a cause or a consequence of poor marital quality? Journal of Social and Personal Relationships, V. 21, 217-230. Doi:

https://doi.org/10.1177/0265407504041384

Pryor, J. \& Rogers, B. (2001). Children in changing families: Life after parental separation, Boston: Blackwell

Rhee, S.H. \& Waldman, I.D. (2002). Genetic and environmental influences on antisocial behavior: A metaanalysis of twin and adoption studies. Psychological Bulletin, N.128, 490-529. Doi: https://doi.org/10.1037/0033-2909.128.3.490 
Rodgers, J., Cleveland, H., Van Den Oord, E. \& Rowe, D. (2000). Resolving the debate over birth order, family size, and intelligence, American Psychologist, N.55, 599-612. Doi:

https://doi.org/10.1037/0003-066X.55.6.599

Rutter M., et al. (2001). Testing hypotheses on specific environmental causal effects on behavior, Psychological Bulletin, N 127, 291-324. Doi: https://doi.org/10.1037/0033-2909.127.3.291

Scarr, S. \& McCartney, K. (1983). How people make their own environments: A theory of genotype environment effects, Child Development, N.54, 424-435. Doi:

https://doi.org/10.1111/j.1467-8624.1983.tb03884.x

Schleider, J.L. \& Weisz, J.R. (2013). Relation Between Parent Psychiatric Symptoms and Youth Problems: Moderation through Family Structure and Youth Gender, Child. Psychol, N. 42, 195204. Doi: https://doi.org/10.1007/s10802-013-9780-6

Schoen, R., Astone, N. M., Rothert, K., Standish, N. J. \& Kim, Y. J. (2002). Women's employment, marital happiness, and divorce, Social Forces, 81, 643-662. Doi:

https://doi.org/10.1353/sof.2003.0019

Stanley, S. M., Rhoades, G. K. \& Markman H. J. (2006). Sliding versus deciding: Inertia and the premarital cohabitation effect, Family Relations, V. 55, 499-510. Doi:

https://doi.org/10.1111/j.1741-3729.2006.00418.x

Sweeney, M. M. \& Phillips, J. A. (2004). Understanding racial differences in marital disruption:

Recent trends and explanations, Journal of Marriage and Family, V. 66, 639-650. Doi:

https://doi.org/10.1111/j.0022-2445.2004.00043.X

Tach, L. \& Halpern Meekin, S. (2009). How does premarital cohabitation affect trajectories of marital quality? Journal of Marriage and Family, V. 71, 298-317. Doi:

https://doi.org/10.1111/j.1741-3737.2009.00600.x

Teachman, J. (2002). Stability Across Cohorts in Divorce Risk Factors, Demography, N.39, 331351. Doi: https://doi.org/10.1353/dem.2002.0019

Teachman, J. (2003). Premarital sex, premarital cohabitation, and the risk of subsequent marital dissolution among women, Journal of Marriage and Family, V. 65, 444-455. Doi:

https://doi.org/10.1111/j.1741-3737.2003.00444.x

Thornton, A. (1991). Influence of the marital history of parents on the marital and cohabitation experiences of children, American Journal of Sociology, N. 96, 868 - 894. Doi:

https://doi.org/10.1086/229611

Treas, J. \& Giesen, D. (2000). Sexual Infidelity among Married and Cohabiting Americans, Journal of Marriage and the Family, N.62, 48-60. Doi: https://doi.org/10.1111/j.17413737.2000.00048.x

Waite, L. \& Lillard L. (1991). Children and Marital Disruption, American Journal of Sociology, N.96 (4), 930-953. Doi: https://doi.org/10.1086/229613 